\title{
ATTITUDES TO ARV ACCESS AND FACTORS UNDERMINING HIV/AIDS PREVENTION. LESSONS FROM THE 2008 TSABONG STIGMA CASE STUDY (BOTSWANA)
}

\section{Simon Kang'ethe}

\section{STUDY AIMS AND OBJECTIVES}

Though the broad research study from which this article is derived was to assess the prevalence of stigma and discrimination in the Tsabong District, the aim of this article is to assess the attitudes, views, perceptions and thinking of selected Tsabong communities and people living with HIV/AIDS on access to ARV drugs and the administrative success against those factors and challenges that undermine the prevention efforts especially among the people living with HIV/AIDS and who are on ARVs.

\section{PROBLEM STATEMENT}

International, regional and local concern about the impact that stigma and discrimination have had on the country's response to the HIV/AIDS campaign, and the increased challenges of HIV/AIDS response among the people living with HIV/AIDS in the Tsabong District, led the BONEPWA research team to embark on this study and undertake an informed and evidencebased analysis to further chart out interventional directions and strategies (NACA, 2002; UNAIDS, 2000c; UNDP, 2004). This was done in order to investigate possible factors besides stigma that compromised the success of the ARV programme in Tsabong. The findings were likely to shed light on the issue and possibly bolster the government's and NGOs' responses as they address these challenges.

The government of Botswana and the organisation of BONEPWA, whose goal is strengthening response and interventions to respond to the HIV/AIDS pandemic, have been greatly perturbed by cases of drug defaulting, reported cases of alcohol abuse and increased cases of repeated pregnancies especially among the PLWHAs (Kang'ethe, 2007a, 2007b, 2007c) These were critical phenomena demanding further research. If not timeously addressed, they could be pointers to a failure of the general national response. It was therefore crucial that BONEPWA embark on this important research to make evidence-based findings that would inform local, national and international interventions.

\section{INTRODUCTION}

A candlelight memorial ceremony was held on 23 June 2009 hosted by the Gaborone District Multisectoral Aids Committee (DMSAC) to remember more than 3 million people in the world who have died of HIV/AIDS; to encourage close to 113000 persons living with advanced HIV in the country to continue the struggle and offer a powerful response; and to take stock of the HIV/AIDS campaign successes and shortfalls in the country. One of the pertinent messages and concerns expressed on that occasion was that the success of ARV access and administration in Batswana was regretfully not moving in tandem with the prevention of the disease (BONEPWA, 2008; MOH/JHPIEGO, 2009; NACA, 2008). The message from the speakers caused frustration and despondency as it dashed the hope that the country had been nurturing of having zero infections by 2016, when the country will be celebrating its fifty years of independence (Central Statistics Office (CSO), 2008; Kang'ethe, 2006b; Vision 2016, 1997). This also confirmed the BONEPWA research team's findings from Tsabong that people were increasingly departing from the path of prevention as they express their greater sexual freedom 
after ARVs had miraculously improved their health (BONEPWA, 2008). Though the candlelight message did not indicate that all was lost through increased access to ARVs moving diametrically opposite to success in prevention, it did convey the point that the efforts that the government, non-governmental organisations and private individuals had invested for years in fighting the epidemic were not producing the expected commensurate dividends. This is partly evident from the 2008 Botswana AIDS Impact Survey (BAIS) III results, which were released in June 2009, that indicated a change of population-based prevalence from $17.1 \%$ in 2004 to the current figure of $17.6 \%$, i.e. an increase of $0.5 \%$ (CSO, 2005, 2008).

Subjective information derived from several varied discussions with members of the support groups of people living with HIV/AIDS across the country with this author, who facilitated the empowerment of 20 support groups under the Botswana Network of People Living with HIV/AIDS (BONEPWA) and under the auspices of Skillshare International funding, indicates that the possible increase in infection could be driven by the fact that many people no longer fear becoming infected because ARVs are free. This thinking was reinforced by the Tsabong research study findings that people generally, and in particular the PLWHAs, were not taking the prevention measures seriously (BONEPWA, 2008). The Tsabong research participants also indicated that many people living with HIV/AIDS were also disenchanted and fatigued by inadequate material and psychosocial support from the government, NGOs, campaign-friendly private companies and individuals that assist the government in responding to the HIV/AIDS pandemic (BONEPWA, 2008; Kang'ethe, 2006a). They also quoted social challenges such as poverty, stigma and discrimination, and general desperation intrinsically part of living with the virus (MOH/JHPIEGO, 2009).

Perhaps this laxity about prevention could explain the widespread lack of adherence to medication, excessive intake of alcohol and cases of repeated pregnancies among those living with the virus (BONEPWA, 2008; Kang'ethe, 2007b, 2007c; MOH/JHPIEGO, 2009). While ARV access and administration has on the one hand contributed to reduced stigma and the discrimination associated with the HIV/AIDS phenomenon in the country, giving the country reason to be proud of, on the other hand the effect is giving people relief, improved self-esteem, confidence and sexual freedom that people are misusing, the result being the undoing of the good works and positive impact of the ARVs to their health (BONEPWA, 2008). This is unfortunately eroding the moral and preventive awareness that the campaign machinery in Botswana has hugely invested in. This has not only confronted the national campaign machinery with a dilemma, but has also caused the national campaign architects to panic. The BAIS III results have sent signals indicating that, though the war on HIV/AIDS is being won through national access and the roll-out of ARVs, it is not being sufficiently successful in some areas of prevention. This poses the danger that the immense hope that the country has of reversing what used to be unrelenting upward wave of the epidemic could be dashed (CSO, 2008).

\section{METHODS AND STUDY SETTINGS Research design}

The study used a qualitative design and was explorative and descriptive in nature. The study also used participatory methodologies of focus group discussions, complemented and triangulated with data from in-depth one-to-one interviews and participant observation. This is justifiable because the study sought to explore the thinking, feelings, attitudes and perceptions of the support group members, health-service providers and a few leaders and administrators on the extent of stigma in the Tsabong region generally and the challenges that continue to 
undermine prevention efforts in the Tsabong District. A qualitative research design is concerned with the meaning and sense that the participants make out of the phenomenon under study (Neuman, 2003).

\section{Research instrument}

An interview guide was used to guide six focus group discussions, five from the five support groups in the District and the sixth for the service providers of the Ghakibane village, including the Tsabong AIDS coordinator and his Peace Corps volunteer, and six in-depth one-to-one interviews, four with the church leaders or their representatives and two with the chiefs. The interview guide consisted of open-ended questions that guided the discussions. The questions facilitated the collection of the data on the behaviour, attitudes and perceptions of the selected Tsabong communities and the PLWHAs on how they perceived the success of ARV administration and access, and the prevention of HIV/AIDS generally. Though the instrument had been constructed to take a maximum of 90 minutes, in some settings the discussions took slightly more time.

\section{Sample selection criteria, data collection and procedure}

Sample selection used convenience sampling and the snowballing technique in that the research team targeted the members of all the support groups in the Tsabong region, the traditional chiefs (digkosis) who were available, and all the church leaders with whom the research team could secure appointments with ease. It was the research team's wish to interview the healthservice providers, but the team managed to have only one focus group discussion in Gakhibane consisting of a nurse, a social worker, a teacher, a Peace Corps volunteer and the District AIDS Coordinator (DAC). In total 51 females and 17 males were involved in the study. This included six focus group discussions, five for the five support groups in Tsabong region, and one conducted at Ghakibane village for the service providers, and six one-to-one interviews, four with the church leaders or their representatives, and two with the Werda and Ghakibane village chiefs (dikgosis) respectively.

BONEPWA, through a letter and several telephonic communications, had asked the office of the District AIDS Coordinator to make appointments for our interviews with our target sample, which he did. All the focus groups and the one-to-one interviews were done at the locality of the people, or where the support groups usually met. This was in the clinics or the health centres. The nurses who usually worked with the support groups joined the focus group discussions of their support group members. They reinforced, corroborated, cross-checked, contrasted and confirmed the support group's opinions.

The focus group discussions were facilitated by this author who represented Skillshare International plus two other officers from BONEPWA who acted as research assistants and represented Forum Syd. While one person asked the questions, the other two wrote responses and noted the participants' temperamental gestures that could add value to the spoken reality. The selection criteria for the participants did not consider factors such as age and gender. Jotting down notes, probing, questioning and discussions formed strategies of collecting the data.

\section{Data analysis}

The data analysis process was done by this author and started with collecting the piles of crude field data notes that had been roughly jotted down. The process of collating the crude data was important. This is because some data were in Setswana, while some were in English. The author happens to be fluent in the Setswana language. The data were then sorted by the use of 
codes. This meant that the data could be arranged easily into groupings that in turn produced themes and sub-themes. This formed the basis of analysis. Quotes, words, analogies, jotted notes were used to inform the data collection, while the assessment of data from the participants' temperaments and gestures by the researcher and his team influenced some findings.

\section{Ethical and legal requirements}

To ensure that the study was administratively and legally correct, all communications and arrangements for interviews with the participants were made through the office of the Tsabong AIDS Coordinator. The office of the District Commissioner had also been informed of the exercise well in advance. The District AIDS Coordinator had also written to the targeted samples requesting their informed consent. The Tsabong DAC understood the activity as one of the BONEPWA planned activities for Skillshare and Forum Syd project activities. He was thankful, because the results could inform robust policy decisions and interventions to curb the prevalence of stigma in Tsabong, and also indicate other evidence-based factors undermining the prevention efforts among the PLWHAs in Tsabong.

Conducting of focus group discussions as part of the BONEPWA organisation's working procedures and activities did not have to follow the research procedures spelt out by the Ministry of Health's Human Research and Development Committee Board.

\section{Research domain}

The empirical data for this research undertaking were collected in October 2008. The BONEPWA research team chose Tsabong District as their research domain because BONEPWA believed that the District was lagging behind other districts in HIV/AIDS interventions and resources. The organisation's 2004 visit to the District had given some indications that the area could be suffering from immense stigma and discrimination. Again, while there was considerable research in many other districts in the country, Tsabong had been avoided because of its distance from Gaborone as well as its aridity and difficult geographical terrain. This justified BONEPWA's interest in the area. It also coincided with a Skillshare research project in the area, and Forum Syd was also engaged in a similar activity to assess the prevalence of stigma in the region. The two projects of the BONEPWA organisation then joined hands to spearhead a research undertaking.

\section{Research Findings}

Profile of the participants

TABLE 1

PARTICIPANTS' GENDER AND SAMPLE DISTRIBUTION

\begin{tabular}{|c|l|c|c|}
\hline \multirow{2}{*}{ NO } & \multirow{2}{*}{ Support group/Service providers/Dikgosis } & \multicolumn{2}{|c|}{ Gender } \\
\cline { 3 - 4 } & & Male & Female \\
\hline 1 & Nkinola Support Group & 0 & 4 \\
\hline 2 & Omaweneno Support Group & 4 & 16 \\
\hline 3 & Draihook Support Group & 3 & 13 \\
\hline 4 & Tsabong Support group & 3 & 8 \\
\hline 5 & Gakhibane support group & 0 & 6 \\
\hline 6 & Service providers & 3 & 2 \\
\hline 7 & Churches & 2 & 2 \\
\hline 8 & Chiefs (Dikgosis) & 2 & 0 \\
\hline TOTAL & & $\mathbf{1 7}$ & $\mathbf{5 1}$ \\
\hline
\end{tabular}


The research did not consider the age and educational level of the participants. It was concerned with the qualitative views, thinking and perspectives of people in the area as far as the stigma and prevention challenges that the PLWHAs were facing. This was to inform evidence-based interventions and response strategies for the BONEPWA programming and national interests. Gender indicated a preponderance of women compared to men. Participants constituted 10 male and 47 female PLWHAs; two community traditional leaders or dikgosis; four church leaders or their representatives; and five service providers (Tsabong District AIDS Coordinator, Tsabong Peace Corps Volunteer, a teacher, a nurse and a social worker). The service providers formed one focus group. The research team consulted the last focus group to correct, augment, contrast, confirm and cross-check the data from the other two sets (PLWHAs, dikgosis and church leaders).

From the research team's subjective perspective, the PLWHA participants in all the focus groups discussions, but very conspicuously in Werda and Onawemeno villages, appeared to be facing acute nutritional challenges. Most research participants, but largely the PLWHA's indicated that finding adequate food to ensure the smooth working of the ARVs was a big challenge. Most of the participants indicated that they were poor and of low educational background, or they had dropped out of school early and that it was difficult for them to get any formal employment other than seasonal piece jobs (temporary casual jobs). The majority of the participants stated that economic frustrations drove them to take excessive alcohol, sometimes irresponsibly. The two chiefs who the research team managed to subject to the in-depth interviews confirmed being passionately involved in the HIV and AIDS campaign, while one admitted living positively with the virus.

\section{Prostitution among the PLWHAs compromises prevention and HIV/AIDS response}

Close to a third of the Tsabong research participants indicated that as a result of poverty and desperation, some people living with HIV/AIDS were resorting to prostitution. This they said was because they needed to feed their children and themselves. In Werda village, for example, some support group members confirmed they were left with no any economic decision but to engage in prostitution. One had this to say:

Some of us have to get food on the table for our children and ourselves. Prostitution has been the only option.

Many support group research participants, especially in Omaweneno, confirmed that many people living with HIV/AIDS were engaged in prostitution. The research team's learnt that despite the lack of towns and a larger population, where prostitution was known to thrive, prostitution in the area was prevalent in that the client could have several partners, each helping out in a different way. While one customer, for example, gives money for food, another one would be giving money for clothes, another one for beer, etc. Participants indicated that this is the form of prostitution that was rampant in the area. These sentiments were captured especially by members of the Omaweneno support group:

People living with the virus are known by communities for sleeping around, taking of excessive alcohol and prostitution.

Desperation, poverty and joblessness are factors behind excessive intake of alcohol and misbehaviour.

People are these days not afraid of the virus. They can afford to do unprotected sex. 


\section{Increased sexual libido from taking ARVs leads to increased sexual activity, which compromises prevention strategies}

The majority of the PLWHAs across all the focus group discussions indicated that most of the PLWHAs were known to openly "sleeping around", either for money or otherwise. They attributed this partly to increased sexual libido that resulted from the use of the ARVs. The participants asked the BONEPWA research team what could be done to the ARVs to reduce their increased sexual libido effect. Some PLWHA participants, especially in Omaweneno, remarked:

It is not that we like too much sex, it is these ARVs that make us have great sexual urge. Sex is irresistible.

These ARVs are making most people to be sexually active. We need the libido effect to be reduced.

\section{Excessive alcohol intake}

Virtually all the research participants admitted that PLWHAs were lacking in discipline. This was because some were openly showing communities they did not care being seen excessively drunk for most of their time. When the research team asked the research participants why they think the PLWHAs were drinking a lot and yet they knew they were on ARV, the research participants stated:

Most PLWHA have lost hope and issues of prevention take second priority.

PLWHAs take alcohol to drown off their life challenges.

Poverty of the PLWHAs makes most of us seek consolation from the bottle. Joblessness is driving most of us into drinking and other bad habits (prostitution).

\section{Repeated pregnancies undermines personal PLWHA response and the HIV/AIDS national campaign}

The majority of the research participants in all the focus group discussions and in-depth interviews expressed concern about the fact that some people living with the virus were involved in unprotected sex. This was indicated by increased cases of repeated pregnancies among those on ARVs. Some participants indicated that some people living with HIV/AIDS, facing immense life challenges such as poverty, joblessness, stigma and discrimination and other social challenges, ignored or turned a deaf ear to the grave consequences of failed adherence. However, some female participants indicated that most PLWHAs are coerced to have unprotected sex by their male partners without being able to resist. A few other participants said that some PLWHAs interpreted the national success of the Prevention of Mother To Child Transmission (PMTCT) as a panacea for those living with the virus and wanted to have children. The following sentiments were expressed to this end:

People are no longer worried about repeated pregnancies. They say PMTCT is now working.

Some of us are forced into unprotected sex by our male partners. We have no strong negotiation power. They are the ones who feed us.

\section{ARVs given on an empty stomach may not achieve desired results}

Virtually all the support group members indicated that, although ARV access and administration was good, their nutritional environment was not conducive to health. Poverty 
and therefore lack of adequate food were compromising the working of the ARV drugs. Participant observation from the research team indicated that most people in the area were lacking food and they were therefore challenged and demotivated to address issues of prevention and the campaign generally. They expressed these sentiments concerning lack of food or adequate food for ARV to work:

Taking ARVs on an empty stomach could drive us fast into the graves.

We suspect taking sorghum porridge (motogo) with the ARVs is not good enough. We have no option. We need to be supported nutritionally.

\section{Cultural dynamics undermining the prevention efforts}

Almost all the research participants blamed cultural dynamics for making women subservient to the extent that they could not control their reproductive sexual health. The participants complained that the fact that women are culturally supposed to be obedient to their husbands has left them vulnerable to a compromised HIV/AIDS response. Participants added that many women were facing difficulties in persuading men to use condoms and that men had refused to go for HIV/AIDS tests. This only aggravated the process of re-infection. Participants, especially from Omaweneno and Draihook villages, indicated that it was adhering to the cultural values that made many people follow the traditional doctors' advice and treatment therapies, which made ARV drug adherence a daunting challenge. Participants also indicated that men were justifying their unfaithfulness through cultural lenses. Many of the participants expressed the following sentiments:

Our men are using cultural lenses and cultural scapegoats to go for other women. They do not appear to fear AIDS.

Culture has made women the slaves of men. Women can not adequately respond to the epidemic, even if they have the will.

Sticking to cultures has made many people to combine traditional and clinics' medication. It is working against their immunity and therefore response to the epidemic.

\section{Gender inequalities and gender-based violence (GBV)}

Horrifying episodes described by some participants and confirmed by many participants in various focus group discussions, especially in Werda and Omaweneno support groups, indicated that cases of gender-based violence were responsible for lowered prevention and undermined HIV/AIDS mitigation factors. Many women indicated they were sexually harassed by their partners. Culture was identified as a factor that dictated and drove these gender power differentials. A greater majority of the women participants indicated that they were not in a position to negotiate for safer sex practices. Women also said that they suspected their partners' unfaithfulness, but indicated their hands were tied and could not do anything. They still needed men in order to take care of their families economically. This theme was underscored by the following statements:

Huge gender power differentials in these areas have made women as mere sex subjects.

Many of our men force us to have unprotected sex and yet we suspect they are not faithful out there.

Most of our partners have refused to go for test. They want to hold that it is only us women who have the virus. We have not been able to surmount that. 


\section{Inadequate services and information}

Although the majority of the research participants indicated that clinics were serving them adequately and giving them information, about a third of the research participants indicated gaps in service and information in the area. They indicated that many AIDS service organisations were generally avoiding the Tsabong area because it was dry and poverty stricken. In Ghakibana village, for instance, the geography of the area and its aridity made information access a big challenge, especially for the people in the settlements. In Bokspit, for instance, the second-line ARVs were not available and participants had to go to Tsabong. Given the poverty in the area, finding transport funds to go to Tsabong posed a big challenge. Information lacuna, therefore, could be a factor derailing the prevention process for the people of Tsabong. The following comments by participants support this view:

The people of Gakhibane village are in information blackout. The geographical terrain and its aridity has made information availability and access a huge challenge.

People who need second-line treatment cannot access them here in Bokspit. One has to go to Tsabong. Transport from here to Tsabong is a big challenge.

\section{Unhealthy conflict between biomedical practitioners and traditional healers challenge prevention}

Virtually all the participants indicated there was no collaboration between the two treatment systems. Participants indicated that many community members had confidence in the traditional healers because of their historical record of assisting the sick. Some indicated that despite the biomedical practitioners' discouragement of the use of the traditional healers' medication, many were still good customers. However, the case of one person who died in the hands of a traditional healer in Werda village and yet he was not HIV positive made many people hesitant to access the services of the traditional healers. They also indicated that people's prevention efforts could be jeopardised by combining the services of the biomedical practitioners and the traditional healers in tandem. The two systems gave advice that was diametrically opposed. The following sentiments were expressed in this regard:

The case of a healer who killed a community member in Werda has made people to relent their faith in traditional healers.

People in this area have deep faith in traditional healers.

We understand that the use of the two systems can compromise the body immunity. But sticking to one system has been a big challenge to most of us here in Tsabong.

Members of health fraternity have been discouraging community members against accessing the services of the healers. But people have found it difficult to leave the therapists they have known and accessed their services since time immemorial.

\section{Discussion of the findings}

Many research undertakings in Botswana have found people living with HIV/AIDS in dire need of nutritional support (MOH/JHPIEGO, 2009. In their research in Kweneng District, Mojapelo, Ditirafalo, Tau and Dohlie (2001) found most people living with HIV/AIDS and their caregivers seriously requiring nutritional support. Studies by Jacques and Stegling (2001), still in Kweneng, also found caregivers and their clients in abject poverty, which could compromise the success of the ARVs among the PLWHAs. It is recommended that the government, NGOs, donors and any care-friendly organisations come together and help people 
start income-generating projects to alleviate poverty. The prevention efforts could be failing because of inadequate nutritional support.

The preponderance of women who come out to support the campaign is a feature that cuts across many research findings in Botswana. In his research in 2004 and 2006 in Kanye, Kang'ethe found that care programmes had over 95\% women (Kang'ethe, 2004, 2006a). Current literature in Botswana indicates inadequate male involvement in the health campaigns, HIV/AIDS campaigns notwithstanding (Kang'ethe, 2009a). This jeopardises the campaign as it fails to benefit from men's better socio-economic, cultural and leadership social capital qualities. The role of the men's sector to mobilise and win men over to respond to issues of health especially HIV/AIDS campaign is critical (Kang'ethe, 2009a).

While data on conventional prostitution exists in Botswana, there may not be much data on the latent prostitution that was revealed among the Tsabong PLWHA clients, whereby a woman would have several sexual partners providing different kinds of assistance in exchange for sexual favours, instead of the conventional transactional sex (BONEPWA, 2008; BOTUSA, 2007). This kind of prostitution did not require urban facilities. It could thrive even in the rural settings. However, it satisfies the definition of prostitution (BONEPWA, 2008). Though sex work and therefore prostitution is illegal in Botswana, a range of literature provides glaring evidence of its existence. Studies by Motlhabane and Chipfakacha (1995) record evidence of sexual behaviours, such as unprotected sex by male sex workers with their male clients; male and female non-commercial partners; anal sex in female sex workers; genital cleansing for STI/HIV prevention and seeking care for STI from about $66 \%$ of the sex workers in Francis Town. The 2007 BOTUSA female sex work study indicated that people living with HIV/AIDS and on ARVs were also engaged in prostitution; while $30 \%$ of the female sex work participants voluntarily revealed their HIV-positive status (BOTUSA, 2007). One PLWHA participant had this to say: "Sick or no sick, you have to go to work. I started ARVs a week back. I have headaches, I feel dizzy. Still I am on the job" (BOTUSA, 2007:31). This proves how prostitution possibly put them into a state of vulnerability and compromised prevention.

Research in 2002 indicated that sex workers had the challenge of care seeking for STI, low condom use and high alcohol intake, especially in Mamuno village, Gaborone city and Kasane town. This necessitated policies and programmes for harm reduction in this population (Wilson \& Project Support Group, 2002). The 2003 contextualisation of sex work for women in Tlokweng among the orphans and the street children in Gaborone and its environs revealed the following factors: high alcohol intake among the sex workers; no fixed premise for prostitution increasing their vulnerability to violence and rape; non-payment for the services; prevalence of STI/HIV and inconsistent condom use by different partners (Ministry of Health (MOH)/Family Health Division (FHD), 2003; Ntseane, 2003). Suggestions from the sex workers in the above research included asking for skills training for income generation, improved working conditions (established apartments or brothels to store/sterilise sex toys, keep condoms, inspect clients, ensure payment); legalisation of their profession to reduce and limit police brutality, rape, sabotage and increased incarceration; skills training on condom use and rapid diagnosis and treatment of STI (Ministry of Health (MOH)/Family Health Division (FHD), 2003; Ntseane, 2003). Luke and Kurz (2002) indicate that trans-generational and transactional sex are very common in Sub-Saharan Africa, where adolescent girls engage multiple partners simultaneously in order to maximise the benefits of these relationships. They extract money and gifts from older men for sexual services. This agrees with the Tsabong BONEPWA study that issues of prevention have taken second place, with ways of economic survival assuming 
the primary position or priority (BONEPWA, 2008). Policy-wise, the country's 2003-2009 Botswana National Strategic Framework II also recognises sex workers as a vulnerable population that requires specific targeted intervention (NSF, 2003). Policy makers need to chart out ways and means of diagnosing the environments making the sex trade thrive and make targeted interventions to change the situation. This would do much to strengthen prevention.

The literature on increased sexual motivation due to high sexual libido from taking the antiretroviral drugs (ARV) is scanty in Botswana. However, while sexual libido is both a scientific and social reality attracting people to sexuality, the research indicators vary. One female client in the 2007 BOTUSA female sex workers study indicated that, because of multiple sexual encounters with different men, she learnt more about the sexual preferences of men. She indicated that sex work allowed her a sexual life and excitement that she did not know before she started the trade. In the same study, other women sex workers suggested that they could even give some clients free sex for exciting and treating them well. Nyanzi, Pool and Kinsman (2000) indicate that in many sexual relationship contexts, condom use is viewed as the responsibility of men, but men believe that condoms reduce sexual pleasure. This has led to many unprotected sexual encounters. In other research by the same researchers, younger women's sexual involvements with older partners were found to be mainly financially driven, with some girls reporting that they enjoy the pleasure of sexual activity with more experienced older partners (Nyanzi et al., 2000). This author thinks that this is due to men's raising and provoking women's sexual arousal and libido.

Contrastingly, other women indicated that they do not enjoy sex with clients and they were only motivated by money and not sexual desire (sexual libido) (BOTUSA, 2007). A study in Tanzania concluded that "material benefits are one of the incentives for the relationship, while sheer love or the expectation of marriage is often of secondary importance or none at all" (Komba-Malekela \& Liljestrom, 1994:140). Another study by Caldwell, Caldwell, Ankrah, Anarfi, Agyeman, Awusabo-Asare and Orubuloye (1993) indicated that in most relationships sexual encounters are mostly controlled by men with little concern for women's sexual desires. According to the author of this article, all the experiences above could partly explain why HIV prevalence in Botswana is not declining, despite all the government's investments, especially in ARVs (BOTUSA, 2007; CSO, 2008). The government needs to establish other ways of allowing the benefits of the ARVs to effectively produce optimal dividends.

Alcohol abuse in Botswana is a common practice (Kang'ethe, 2007c). People living with HIV/AIDS and on ARVs are also caught in the trap. In some other research undertakings, people living with HIV/AIDS state they are taking alcohol excessively as a result of their hopelessness emanating from poverty, joblessness, stigma and discrimination (BONEPWA, 2008; BOTUSA, 2007; Kang'ethe, 2007a,c). The finding that alcohol intake lures people into encounters of a sexual nature concurs with research findings by this author in Botswana that indicated that alcohol inclines people to sexual behaviour. This could be the same scenario in Tsabong with those on ARVs being suspected of drinking a lot and becoming involved in unprotected sexual activity. Cases of ARVs been left or lost in the bars are a pointer to what excessive intake of alcohol is doing to the prevention efforts in the country (BONEPWA, 2008; Kang'ethe, 2007c). The Tsabong study indicated that people on ARVs were no longer strong or worried about the prevention strategies. This could pose a challenge to drug resistance and therefore decreased response (BONEPWA, 2008). Serious strategies to empower those drinking carelessly as a result of unemployment need to be devised. Strategies for incomegenerating projects could be way of addressing these challenges. 
Repeated pregnancies constitute one of the challenges that the government of Botswana is worried about as it is poses a serious problem for the successful implementation and success of the ARV roll-out in the country. The ARV national roll-out continues to take up a lion's share of the government's national budget (Kang'ethe, 2006a; NACA, 2003, 2005). Many of the clients on ARV who continue to be victims of repeated pregnancies are at risk of reduced immunity that could seriously compromise their health, and sometimes necessitates their moving from one line of treatment to another (Kang'ethe, 2007a). The occurrence of repeated pregnancies is to some extent a sign of failed drug adherence and therefore a deterrent to the prevention of the national campaign. This is why the issue has led to some senior government officials and workers blaming the PLWHAs for repeated pregnancies and spreading the virus to their partners (Moseki, 2007). According to Moseki (2007), this is unfair because the comments do not take into account the critical circumstances on the ground. While women are important players in the national response in Botswana, they have been weighed down by a denial of their human rights in that they have been sexually controlled by men because of the huge gender power differentials in society. This has made it difficult for some women to negotiate for contraceptive use such as condoms. In fact the Tsabong study revealed that very few women on ARVs would like to face the health challenge of repeated pregnancies. They indicated it was embarrassing to their communities and the government at large (BONEPWA, 2008). Many are victims of failed negotiations about condom use, because of men's control over their reproductive health rights, and the fact that many are too poor to be able to afford turning down the demands of their sexual partners. Patriarchy has also had a huge impact in suppressing the women's rights to control their sexual reproductive health (Kang'ethe, 2009a; Lekoko, 2009; Moseki, 2007). Therefore, it is the author's contention that unless the social, economic and cultural forces are adapted to the advantage of women, their capacity to respond to the epidemic may remain low.

On the whole, ARV access and administration is a success story in Botswana. This is internationally recorded in the country meeting the WHO " $3 \times 5$ " targets well in time. Under these targets most countries of the developing world were given a quota of people to access ARVs by the year 2005. The target's rationale was that if all the countries involved would achieve their targeted quotas, 3 million people living with HIV/AIDS would be able to access the ARVs by the year 2005. The country of Botswana was the first among all the countries to achieve its quota target. It had given ARVs to more than 55,000 persons living with HIV/AIDS by the year 2005 (Kang'ethe, 2007b; UNAIDS/WHO, 2005). While accessing ARVs is a good thing, it is important that other structural support systems be explored to extend and influence the results of ARV access. One such important structural challenge is inadequate nutritional support among the people living with HIV/AIDS. The researcher and his team reckoned that most people interviewed looked very needy as far as nutritional support was concerned. The team worried that the ARV success may be compromised by the nutritional challenge. Perhaps the words of South African Development Cooperation (SADC) Executive Secretary, Dr Salomao, quoted in the Botswana Agrinews Magazine of October 2006 need to be taken seriously. He contends that ARV roll-out in SADC countries may not achieve desired results if food security is not adequately addressed. He commented that "There is no point in giving people ARVs on an empty stomach" (Otlhabanye, 2006). As lack of adequate food could negatively influence the efect of the ARVs, the government and the NGOs in the care field need to work out strategies to ensure food security in the region.

Kang'ethe's study in 2004 in Kanye indicated that HIV/AIDS is a poverty-friendly disease (Kang'ethe, 2004). Left with no good economic option, some people living with the virus may 
desperately look for economic survival strategies by any means, sex work being such one attractive venture. Among the girls, 14 years and older, in Swaziland, 20 percent reported being sexually active for financial reasons to fill the poverty gaps in their families, while in another study in rural Tanzania, 52 percent of the female primary school students and ten percent of female secondary school students reported being sexually active for money and presents (MacLean, 1995; Matasha, Ntembelea, Payaud, Todd, Mujaya \& Tendo-Wambua, 1998). According to the 2007 BOTUSA female sex work study, findings indicated women giving an array of reasons for involving themselves in prostitution. Reasons included the inability to meet basic materials needs, and poor family backgrounds making it difficult to acquire the basics. Other reasons that were advanced include: men's failure to provide adequate financial and emotional support; desire to purchase luxury goods; poor educational backgrounds; lack of or poor prospects of work opportunities; and among those who were working, very little pay to make a living. In sex work, the women participants indicated getting enough to cater for their family needs (BOTUSA, 2007).

Culture and poverty may intertwine to direct the women's sexual behaviour. Some studies have indicated that parents of especially the younger women may also be influencing their daughters' sexual position when, for instance, they pressure them to form relationships with older established partners with economic stability, especially to support them in case of pregnancy (Gage, 1998). Other similar studies reveal parents warning their daughters not to bear a poor boy's child (Gorgen, Yansane, Marx \& Millimounou, 1998). Across many countries of the world cultural beliefs, norms, thinking and stereotypes have been found to be some of the underpinning factors making men and women more vulnerable to HIV/AIDS (Kang'ethe, 2009a). According to Orubuloye, Caldwell and Caldwell (1992) and Lekoko (2009), African men, especially, feel that it is their natural rights to have multiple partners, with a preference for younger women. In Botswana Setswana proverbs indicate that it is acceptable for men to be in multiple relationships. Kang'ethe (2009a) mentions Setwana proverbs that endorse this practice, such as "monna ga a gelwe lesaka", which loosely translates as 'a man should not be tied to one woman', "monna ke selepe, o tsamaya o a hapaanelwa, monna ke selepe, o a tsamaya o a rema", which translates to the idea that a man has the freedom to associate with multiple and concurrent partners. Such cultural beliefs are doing more harm to the HIV/AIDS campaign that strongly advocates for faithfulness and sticking to one partner. A lot of research on the effects of culture on the success of HIV/AIDS campaigns needs to be carried out and results worked out fast. This is because the author thinks that HIV/AIDS in Botswana is culturally grounded and yet the campaign machinery has not yet given this issue due consideration.

Gender inequalities continue to be glaringly common scenarios in many societies, especially in the developing world (UNAIDS, 2000a, 2001). The situation continues to undermine women's responses in the HIV/AIDS campaign (Kang'ethe, 2009a). In the 2008 Tsabong study, women reported being sexually harassed by their partners and being forced to have sex without condoms. This could explain to some extent the cases of repeated pregnancies among a large number of the country's PLWHAs. Though the burden of repeated pregnancies cannot be removed from women, the fact of the matter is that we need to explore and recognise the existence of cultural dynamics that control sex and male sexuality in communities (SAFAIDS, 2004/3-4). Women may need to be assisted in their response by men owning the process and supporting the cause. In the absence of that, the HIV/AIDS battle may continue to weigh the country down. In a research study carried out among 1,366 women who attended health centres in Soweto, Johannesburg, and who agreed to be tested for AIDS, women who were beaten by 
their husbands or boyfriends were found to be $48 \%$ likelier to become infected by HIV than their counterparts (http://www.aegis.com/channel/s/AFO40444.html, 2004). The government and care-based organisations need to look especially at the poverty of women and help them start income-generating activities. This could be one of the strongest strategies of empowering women and give them strong control over their reproductive sexual health

While the Tsabong study indicated cases of inadequate services and information in some places such as Gakhibana village because of the geographical challenges of the area, which could impact negatively on the HIV/AIDS response, this author visited most of the Kanye village's clinics in December 2005 and January 2006 and found only about 50\% of most of the important components needed for community home-based care services were available (Kang'ethe, 2006a). Though the government has invested heavily in the HIV/AIDS campaign, monitoring of health services need to be strengthened (NSF, 2003). Many communities in the rural areas still lack adequate information on HIV/AIDS. The availability and monitoring of contraceptives such as condoms need to be strengthened (BONEPWA, 2008). An ad hoc visit by this author to a number of clinics in areas around Mabutsane in 2004 revealed that there were no condoms in most of them. The work ethic and level of supervision among most health-service providers in the country need to be strengthened.

The case of one person who died in the hands of a traditional healer in Werda village in Tsabong District is evidence of the dangers of using the untested concoctions sometimes used by the healers (Pinky, 2001; UNAIDS, 2000b). In the Kanye case study by Kang'ethe (2006a), most participants indicated they did not have enough confidence in the healers and that traditional healers were in the trade to obtain other people's fortunes, with a few participants indicating they had confidence as they had come a long way with them. However, the Tsabong people indicated having much confidence in their healers despite the weaknesses inherent in their therapies (BONEPWA, 2008). The Kanye as well as Tsabong studies indicated the existence of bad blood between the two service providers. However, both the Tsabong study as well as Kanye study recommended to the government to map a strategy which could bring the two service provider together for the sake of the HIV/AIDS campaign. This is because of the awareness of each service provider's unique strengths that could be of utmost use if shared mutually between the two parties (Kang'ethe, 2009b).

\section{CONCLUSION}

The government of Botswana needs to be acknowledged for its formidable efforts to place prevention strategies in place. The national roll-out of the antiretroviral drugs has made the formerly desperate nation glimmer with hope for the future. But the success in ARV access and administration has not been commensurate with prevention results. People living with HIV/AIDS have failed to adequately rise to the challenge and take advantage of the ARVs sufficiently. Instead, cases of increased alcohol intake, repeated pregnancies and weaker adherence to the ARV regime have continued to derail and to undermine the prevention efforts. This has left the government machinery desperate and in a dilemma. Perhaps other factors of social, economic and cultural environments need to be revisited to assess the effect they may be having on the intended beneficiaries. Poverty, especially, needs critical address. Factors such as the nutritional challenges need to be addressed to ensure that HIV/AIDS prevalence takes a downward turn instead of the current upward trend (CSO, 2008). 


\section{REFERENCES}

BONEPWA. 2008. An exploratory informal research survey investigating the state of stigma and discrimination in Tsabong. 27th-31st October 2008. A Draft.

BOTUSA. 2007. Needs assessment of female sex workers in major towns, mining towns and along major roads in Botswana. Final Report, June.

CAldWEll, J., CALDWEll, P.E., ANKRAH, P.E., ANARFI, J., AGYEMAN, D.K., AWUSABO-ASARE, K. \& ORUBULOYE, I.O. 1993. African families and AIDS: context, reactions and potential interventions. Health Transition Review, 3:1-16.

CENTRAL STATISTIC OFFICE (CSO). 2005. Botswana HIV/AIDS Impact Survey II (BAIS II). National AIDS Coordinating Agency (NACA). Gaborone: Government Printers.

CENTRAL STATISTIC OFFICE (CSO). 2008. Preliminary Botswana HIV/AIDS Impact Survey III (BAIS III). National AIDS Coordinating Agency (NACA). Gaborone: Government Printers.

GAGE, A.J. 1998. Sexual activity and contraceptive use: the components of the decision making process. Studies in Family Planning, 29(2):154-166.

GORGEN, R.M., YANSANE, L., MARX, M. \& MILLIMOUNOU, D. 1998. Sexual behaviour and attitudes among unmarried urban youths in Guinea. International Family Planning Perspectives, 24(2):65-71.

JACQUeS, G. \& STegling, C. 2001. Panacea or Perfidy. Paper presented at the $3^{\text {rd }}$ International Conference on Social Work in Health and Mental Health, July 1-5, Tampere, Finland.

KANG'ETHE, S.M. 2004. Issues and challenges of Community Home Based Care in Africa. University of Botswana. (Unpublished Masters of Social Work research essay)

KANG'ETHE, S.M. 2006a. Contribution of caregivers in community home based care programmes: the case of Kanye, Botswana. Potchefstroom: University of the North-West. (PhD Dissertation)

KANG'ETHE, S.M. 2006b. Spirit of "botho" in care giving arena key to Vision 2016 victory. Mmegi Newspaper, $28^{\text {th }}$ December, 7.

KANG'ETHE, S.M. 2007a. Beware of narrow agendas. Botswana Guardian Newspaper, $3^{\text {rd }}$ August, 8-9.

KANG'ETHE, S.M. 2007b. Botswana Hits World Health Organization Targets. Botswana Guardian Newspaper, $9^{\text {th }}$ March, 7.

KANGETHE, S.M. 2007c. Alcohol abuse undermines our HIV/AIDS Campaign. Botswana Guardian Newspaper, $13^{\text {th }}$ April, 8.

KANG'ETHE, S.M. 2009a. Inadequate male involvement in health issues. The cause of gender skewed HIV and AIDS situations in Botswana. In: MAUNDENI, T., OSEI HWEDIE, B.Z., MUKAAMAMBO, E. \& NTSEANE, P.G. (eds) Male involvement in sexual and reproductive health. Prevention of violence and HIV/AIDS in Botswana. Cape Town: Made Plain Communications. 
KANG'ETHE, S.M. 2009b. Traditional healers as caregivers to HIV/AIDS clients and other terminally challenged persons in Kanye community home based care programme, Botswana. Journal of Social Aspects of HIV/AIDS, 6(2):83-91.

KOMBA-MALEKELA, B. \& LILJESTROM, R. 1994. Looking for men. In: TUMBOMASABO, Z. \& LILJESTROM, R. (eds) Chelewa Chelewa. The dilemma of teenage girls. The Scandinavian Institute of African Studies. Uppsala, Sweden.

LEKOKO, R.N. 2009. A generation in jeopardy. Sexually active women in patriarchal cultural settings and HIV and AIDS. In: MAUNDENI, T., OSEI HWEDIE, B.Z., MUKAAMAMBO, E. \& NTSEANE, P.G. (eds) Male involvement in sexual and reproductive Health. Prevention of violence and HIV/AIDS in Botswana. Made Plain Communications, Cape Town.

LUKE, N. \& KURZ, K.M. 2002. Cross-generational and transactional sexual relations in Sub Saharan Africa. Prevalence of behaviour and implications for negotiating safer sexual practices. ICRW, PSI.

MacLEAN, P. 1995. Sexual behaviours and attitudes of high school students in the Kingdom of Swaziland. Journal of Adolescent Research, 10(3):400-420.

MATASHA, E., NTEMBELEA, T., PAYAUD, P., SAIDI, W., TODD, J., MUJAYA, B. \& TENDO-WAMBUA, L. 1998. Sexual and reproductive health among primary and secondary school pupils in Mwanza, Tanzania: need for intervention. AIDS Care, 10(5):571-582.

MINISTRY OF HEALTH (MOH)/ FAMILY HEALTH DIVISION (FHD). 2003. Situation and response analysis for the urban youth project in Botswana. Draft Summary. Gaborone.

MINISTRY OF HEALTH (MOH)/JHPIEGO. 2009. Situational Analysis of the care and treatment needs of PLWHA in Botswana. Draft Report. Gaborone.

MOJAPELO, D., DITIRAFALO, T., TAU, M. \& DOEHLIE, E. 2001. Client satisfaction and providers' perspective of home based care in Kweneng District. Botswana: Gaborone. (Unpublished Report)

MOSEKI, O. 2007. Women living with HIV/AIDS and their reproductive rights: a human rights position. The Botswana Review of Ethics, Law and HIV/AIDS, 1(1):3-7.

MOTLHABANE, N.M. \& CHIPFAKACHA., G. 1995. KAP survey on STD, HIV and AIDS among commercial sex workers: the Francistown experience. Journal of the Medical and Dental Association of Botswana, 25(1):25-30.

NATIONAL AIDS COORDINATING AGENCY (NACA). 2002. Status of the 2002 National response to the UNGASS declaration of commitment on HIV/AIDS. UNICEF, UNAIDS, ACHAP, AIDS STD UNIT, Gaborone.

NATIONAL AIDS COORDINATING AGENCY (NACA). 2003. Botswana 2003 Second Generation HIV/AIDS Surveillance. A Technical Report, December, Gaborone, Botswana.

NATIONAL AIDS COORDINATING AGENCY (NACA). 2005. Botswana Second Generations HIV/AIDS Surveillance. Technical Report, Gaborone.

NATIONAL AIDS COORDINATING AGENCY (NACA). 2008. Progress report of the National Response to the UNGASS Declaration of commitment on HIV/AIDS. ACHAP/UNAIDS. 
NATIONAL STRATEGIC FRAMEWORK (NSFII). 2003. Botswana National Strategic Framework II 2003-2009. Gaborone, Botswana.

NEUMAN, L.W. 2003. Social research methods - quantitative and qualitative approaches. Boston, M.A.: Allyn \& Bacon.

NTSEANE, P.G. 2003. A needs assessment study of sex workers in Botswana: the case of Tlokweng Village. Gaborone: ACHAP and South-East DMSAC report series.

NYANZI, S.R., POOL, S. \& KINSMAN, J. 2000. The negotiation of sexual relationships among school pupils in South Western Uganda. AIDS Care, 13(1):83-98.

ORUBUlOYE, I.O., CALDWELL, J.C. \& CALDWELL. P. 1992. Diffusion and focus in sexual networking: identifying partners and partners' partners. Studies in Family Planning, 23(6):343-351.

OTLHABANYE, M. 2006. No point giving people ARVs on empty stomachs. Agrinews, 37(10).

PINKY, M. 2001. The role of traditional healers and doctors, coping mechanism of CHBC patients and the family, Published Abstract no. 38. on $1^{\text {st }}$ Regional CHBC conference, March, 2001 at Boipuso Hall, Gaborone.

SAFAIDS. 2004/3-4. Sexual health exchange. Exchange worldwide experiences. [Online] Available: www.sexualexchange.org.

UNAIDS. 2000. Caring for carers. Managing stress in those who care for people with HIV and AIDS. UNAIDS Case study. May. Geneva. Switzerland.

UNAIDS. 2000a. Collaboration with traditional healers in HIV/AIDS prevention and care in Sub -Saharan Africa. A literature Review, Geneva, Switzerland.

UNAIDS. 2000b. HIV and AIDS-related stigmatisation, discrimination and denial: forms, contexts and determinants. UNAIDS Best practice Collection (UNAIDSA/00.16E).

UNAIDS. 2001. Parents providing care to adult sons and daughters with HIV/AIDS in Thailand. UNAIDS Case Study, November. Geneva, Switzerland.

UNAIDS/WHO. 2005. AIDS epidemic update. December.

UNDP. 2004. Millennium development goals. Status Report, 2004. Gaborone: Government Printers.

VISION 2016. 1997. Towards prosperity for all. Presidential task group for a long term vision for Botswana, September. Gaborone: Government Printers.

WILSON \& PROJECT SUPPORT GROUP (PSG). 2002. An assessment of sex work along Botswana's major population and transport corridors. Gaborone, Botswana.

\section{INTERNET WEBSITE}

[Online] Available: http://www.aegis.com/channel/afo40444.html. 2004. Male violence towards women boosts HIV risk. South African study. [Accessed: 30/04/2004]. 
Acknowledgement: This article greatly acknowledges Zorani Kraai and Anna Lee, both of BONEPWA and working under the Forum Syd sponsored programme, for their role in data gathering exercise in Tsabong in 2008.

Dr Simon M Kang'ethe is a social worker for Skill Share International and attached to the Botswana Network of People Living with HIV/AIDS (BONEPWA) Botswana. 